\title{
THE PSYCHOLOGY OF VOTING ACTION ON the Psychological Origins of Electoral Research, 1939-1964
}

\author{
MAX VISSER
}

\begin{abstract}
This article examines the development of psychologically oriented voting behavior research between 1939-1964. It intends to show the psychological basis of the Columbia and Michigan approaches and its implications for the analysis of electoral behavior. It is argued that, in spite of the large differences commonly perceived between these two approaches, there is much similarity between them, both with regard to their psychological roots as to their principal conclusions.
\end{abstract}

\section{INTRODUCTION}

The study of voting behavior is one of the oldest and most venerable branches of political science, with antecedents going back to the beginning of this century. At first electoral research was predominantly demographically oriented, using official election and census statistics as its principal data. With the advent of the first public opinion polls in the 1930s it became possible to research voting choices at the level of the individual voter; the use of such polls and surveys has quickly proliferated since then to become the dominant mode of inquiry in the field of electoral research, if not in most areas of social science.

Partly forced by the aggregate nature of their data, the first electoral analysts adopted a macro-sociological view of voting behavior, exploring voting tendencies among occupational, religious and ecological groups. The advent of opinion polls and surveys made it possible to analyze electoral behavior in a more psychological way, and as the use of surveys spread, the quality and quantity of psychologically oriented voting research increased with it, becoming the dominant paradigm in electoral research.

Psychology probably decisively entered the field of voting behavior research in 1939, when Paul Lazarsfeld and his staff at Columbia University set out to plan the Erie County election study. Lazarsfeld received his training at the Psychological Institute of the University of Vienna and hoped to extend his earlier psychological analyses of human actions to the field of voting behavior. In the late 1940s a group of voting analysts at the University of Michigan began to criticize the Columbia approach, developing an alternative view of voting action, based on Kurt Lewin's field theory. Although this Michigan approach is influential to the present time, its development essentially was concluded in 1964, with the publication of Philip E. Converse's paper on belief systems.

This article examines the development of psychologically oriented electoral research during these first twenty-five, formative years. It intends to show the psychological basis of the Columbia and Michigan approaches and its implications for the analysis of electoral behavior. More specifically it will be argued that, in spite of the large differences commonly perceived between these two approaches, there is much similarity between the two schools, both with regard to their psychological roots as to their principal conclusions.

Max VISSER is in the Department of Public Administration \& Political Science, University of Twente, P.O. Box 217, 7500 AE Enschede, The Netherlands. 
In order to attain these goals I will first discuss the work of Lazarsfeld and the Columbia school, followed by a discussion of the Michigan approach and its psychological antecedents. Finally, I will compare the two schools and assess similarities and differences between them.

\section{Lazarsfeld and the Empirical Analysis of Voting Action}

Paul F. Lazarsfeld (1901-1976) entered the University of Vienna after the first World War and received his $\mathrm{Ph} . \mathrm{D}$. in applied mathematics in 1925 . In the early 1920 s he studied and worked with the German psychologists Karl and Charlotte Bühler, then engaged in developmental psychology. In 1925 Lazarsfeld founded the "Wirtschaftspsychologische Forschungsstelle" as a part of the Vienna Psychological Institute, dedicated to the application of psychology to social and economic problems. Until his emigration to the United States in 1933, Lazarsfeld acted as research director of the "Forschungsstelle," directing and stimulating a great number of research projects for business firms, city agencies and others. ${ }^{1}$

From the Bühlers Lazarsfeld took over a strong interest in the empirical study of human action, an interest that would occupy him for the rest of his professional life. Action analysis could be applid to all kinds of actions, choices and decisions, from consumer purchases and occupational choice to migration and voting decisions. Lazarsfeld searched for convergences between different approaches and methods, and for him the analysis of action offered the promising prospect "of merging the study of individuals with the study of the aggregate effects of individual actions, and thus as a way of merging psychology and sociology." 2

Lazarsfeld also adopted Karl Bühler's method of detailed and repeated introspective interviewing, and combined this with his own interests in statistics and applied mathematics. Thus, in his Vienna years, the groundwork was laid for the greater part of Lazarsfeld's later substantive and methodological contributions to the social sciences.

The basic ideas of Lazarsfeld emerged from his earliest publications. In an analysis of motives behind Viennese adolescents' choices of occupation Lazarsfeld followed Karl Bühler's fundamental observation that "jede Handlung aus einer Konvergenz von Bedürfnis und Gelegenheit entsteht." ${ }^{3}$ Obviously, occupational choice constituted an action (Handlung) in Bühler's sense, and therefore its motives should also be classified in terms of inner needs (Bedürfnis) and external occasions (Gelegenheit). However, these inner and outer factors should not be treated independently, because they interact in the actor's subjective reality: existing needs may influence the actor's perception of occasions, while the occurrence of occasions may determine the degree to which satisfaction of needs may take place. A correct explanation of occupational choice should concentrate on this process of interaction between different motives in the course of the adolescent's development. For each individual the choice process should be researched through detailed introspective interviews, in which the course of the decisional process is recorded from the very beginning to the ultimate choice of occupation.

After his emigration to the U.S. Lazarsfeld refined his theory of action. ${ }^{4} \mathrm{He}$ distinguished the inner factors in motives and mechanisms. Motives refer to "the set of inner guiding processes which determine the movement of behavior toward ends or goals ... [The processes] refer to some [conscious or unconscious] condition of tension or disequilibrium within the person, with the ensuing conduct serving to relieve the tension or to reestablish equilibrium." The variety of different motives that a person may have is reflected in specific attitudes, which Lazarsfeld defines as "action tendencies toward 
particular objects," and which are the immediate determinants of behavior. ${ }^{5}$ Mechanisms are the mental, sensory and motoric capacities that the person has, and these capacities largely determine in what specific way motives will produce a specific action.

Lazarsfeld further elaborated the process aspect of action by stressing the importance of a time-line. The concrete action is a culminating point of a process extending over time, and a real understanding of any action must involve a developmental analysis of "what went before."

Such an analysis of action requires an elaborate methodology. The simple question "Why did you perform this action" typically results in a plethora of incomparable or meaningless responses, and Lazarsfeld soon concluded that in the absence of a natural structure of action, the investigator himself must impose a structure on it, depending upon the purpose of the investigations. ${ }^{6}$ Out of these considerations grew the panel methodology to research actions in an empirical way.

It was Lazarsfeld's basic idea that voting action was essentially similar to consumer decisions or occupational choices, when he entered the field of voting studies in 1939. He decided to study voting decisions, instead of consumer purchases, because of distinct methodological advantages of the former.

The study of the 1940 U.S. presidential election in Erie County, Ohio, had two goals, one substantive and one methodological. The first goal was to study "votes in the making": how do voters make up their minds, and what is the role of the mass media in that process? The second goal involved the study of the panel method itself: what is the effect of repeated interviewing on panel respondents?

To answer these questions, a panel of 600 respondents was interviewed seven times in the seven months preceding the election, while the effects of the panel method were countered by using four separate, matched control groups. A community rather than a national sample was selected in order to keep the possible array of campaign stimuli under investigative control. Elaborate accounts were made of the flows of information in all Erie County media, coinciding with the seven panel interview waves, so that subjective and objective factors would be researched simultaneously.

However, when the first results came in, it turned out that voting decisions differed from consumer decisions in some crucial aspects. First, nine out of ten voters had made their decision well before the start of the campaign, so that the whole elaborate research design had relevance for only fifty-four respondents out of the original 600 , a number far too small to permit generalizing or to state statistically significant conclusions. Secondly, in the absence of substantive change the influence effects of the media campaigns could not clearly be discerned and analyzed. And, finally, the different personality variables intended as measures of the respondents' deeper motives did not show any noticeable effect in the analysis.

The data so much contradicted the original expectations of Lazarsfeld and his staff that, out of disappointment with the results of the first analyses, they laid them aside for a year. When Lazarsfeld, Bernard Berelson and Hazel Gaudet finally published the results in The People's Choice (1944), they did not mention the original action model, nor did they say much about the panel methodology. Instead, a different picture of voting action emerged, largely as a result of a multivariate elaboration of the data and the inductive finding of relationships between variables originally included for other research purposes. ${ }^{7}$

In this analysis of voting action a heavy emphasis was laid on external influences, in particular on the impact of the voters' primary groups. Voting action was seen as 
almost wholly determined by social forces, in several aspects. First, social groups displayed such clear tendencies toward voting for one party or another that Lazarsfeld et al. were able to explain voting choices from only three social characteristics, expressed in an Index of Political Predisposition. ${ }^{8}$ Second, voting intentions supported by the voter's primary groups were far more reliably carried out than intentions lacking such support. ${ }^{9}$ Furthermore, the social groups interposed themselves between the formal communication media and the individual voter: media messages were picked up by the groups' most active members (opinion leaders) and disseminated to the less involved group members in a form congenial to the group members' political standards. Since these members individually also tended to view political propaganda in a highly selective way, shielding themselves from opinions unfavorable to their own, there was little opportunity for parties and other political actors to convert voters to their cause. ${ }^{10}$

Changes in voting actions and intentions did occur, though, but these too were dependent upon the social process. Voters who in the course of the campaign vacillated between different parties or changed their vote from one election to another were more often than not subjected to cross-pressures, i.e., diverging forces pulling the voter in different directions. These cross-pressures were considered mainly social in nature, referring to conflicting pressures arising from a voter's memberships in social groups with different voting tendencies. Although Lazarsfeld and his colleagues acknowledged the possibility of psychological cross-pressures, these did not play a noticeable role in their analyses. ${ }^{11}$

Out of the original action model there appeared an account of voting choices that was almost completely due to social influences, but lacking on the aspects of motives, attitudes, and mechanisms; it was a description of the vote, well summarized in the statement "a person thinks, politically, as he is, socially. Social characteristics determine political preference." 12

Eight years later Lazarsfeld and his staff returned to the study of voting. The object of investigation was the 1948 U.S. presidential election in Elmira, New York. The study was intended as a replication of the Erie County research, with an essentially similar design, but with some important substantive additions to the questionnaire and the description of the community. It involved a four-wave panel of 1,000 respondents each, with no control groups. In comparison to the earlier study, more attention was given to the activities of local party and other political organizations, and to the respondents' positions on and perceptions of issues; less effort was put in measuring exposure to campaign items in general. Finally, the report of the 1948 study (Voting, 1954) was different from The People's Choice in modes of analysis and interpretation. ${ }^{13}$

With regard to the substantive results, Voting followed the emphasis in the earlier report on the social environment of the voter. However, the discussion of group associations, which were solely regarded as primary in nature in The People's Choice, was supplemented by a treatment of group identifications and group perceptions. ${ }^{14}$ Voting also contained an important discussion of the role of issues, and the voters' perceptions of the issue positions of the two candidates. Cross-pressures were now considered to be social psychological in nature, as conflicting forces inducing tensions in the person. ${ }^{15}$ Lazarsfeld et al. concluded that the psychological function of selective perception is to avoid these tensions, i.e., to retain harmony with one's primary and secondary groups as well as in one's ideas. ${ }^{16}$

With the inclusion of group and political perceptions Lazarsfeld returned to the original action scheme, in which the actor's reality is simultaneously formed by his subjective state of mind and by objective events that impinge upon him. The odd balance 
of the early work, so confined to external influences, therefore was redressed in the later study, giving due weight to motives, attitudes and mechanisms.

Voting was the final volume on voting behavior of Lazarsfeld's research group. Several other studies on aspects of political behavior emanated from his Bureau of Applied Social Research, but no new comprehensive studies of "votes in the making." 17 The reasons for this withdrawal were financial and organizational: the Bureau had difficulty in finding financial support, and in general, "it was destined to remain, like its founder... somewhat marginal to the mainstream of American academic life ... [The Bureau] survived for forty years, generally amidst administrative chaos, and with conspicuously little financial support from the university." 18 The future of voting studies in an institutional sense belonged to other institutes, in particular the Survey Research Center of the University of Michigan.

\section{The Field Theory of Voting Action}

Although several sources have contributed to the development of the Michigan approach to electoral behavior, the most important influence came from Kurt Lewin's field theory.

Kurt Lewin (1890-1947) studied and worked at the University of Berlin under Gestalt psychologists Max Wertheimer and Wolfgang Köhler, becoming a "Dozent" in 1922 and "außerordentlichen Professor" in 1927. Following the Nazi seizure of power in 1933, he did not return to Berlin from a six-month stay at Cornell University, but remained in the United States. In 1935 he moved to the Child Welfare Research Station of the University of Iowa, and ten years later he returned to the east to become the director of the new Research Center for Group Dynamics at the Massachusetts Institute of Technology. ${ }^{19}$

Although trained and working at the center of Gestalt theory, Lewin could never truly be called an orthodox Gestaltist. Gestalt notions like the isomorphism thesis or the law of "Prägnanz" did not receive much attention in his work, nor was he overly concerned with introspective experiments on perception and thinking. Lewin's interest lay in dynamic psychology, in uncovering the dynamics of human action. He devised a field theory of motivation, the Gestaltist adaptation of the only motivation theory existing at that time, the Freudian system. ${ }^{20}$

A point of departure in both Lewin's and Freud's theories were human needs; these produce tensions in the person, impelling him to activity directed at their gratification. Needs, Lewin reasoned, thus have the character of organizing actions. Factors in the person's subjective field which contribute to need satisfaction acquire a positive valence; they exert a force on the person to approach them. Field factors which impede a gratification of needs, however, attain a negative valence, exerting a force on the person to avoid them. What action actually will occur is dependent upon the whole constellation of forces in the field. The final consummatory action conforms to the resultant of these forces and reduces the tensions in the person, leading to a momentary equilibrium in the field. ${ }^{21}$

Lewin's inclusion of motivational factors altered the orthodox Gestalt view of the field. The tendency toward "good" Gestalt no longer was the sole organizing force in the behavioral field; human drives, needs and intentions also were responsible for structuring the total life space of the person. In positing a relationship between needs and the cognitive structure of the field Lewin dissented from the Gestalt rule that the dynamics of perceptual organization only inhere in the perceptual data themselves, and not in the "eye of the beholder." 
Without exaggeration it can be said that Lewin was by far the most successful psychologist to come from Europe to the United States. While the Gestalt psychologists in general changed the study of perception in the States, they suffered the handicap of "being holistic prophets of theoretical psychology in [the] atomistic, relatively a-theoretic wilderness [of behaviorism]." 22 Most Gestalt notions eventually merged and disappeared in American mainstream psychology, yet they survived in social psychology, due to Lewin's influence. His field concept proved capable of infinite extension, and soon was brought to bear on social processes like group cohesion, intragroup communication, maintenance of group standards and intergroup perceptions. ${ }^{23}$

Lewin's impact was probably more due to his original experimentation and stimulating personality than to the topological theories he espoused. Both in Iowa and at M.I.T he influenced many important future American psychologists, among them Dorwin Cartwright, Leon Festinger, Ronald Lippitt, Stanley Schachter, Kurt Back, Harold Kelley, John Thibaut, Morton Deutsch and Albert Pepitone. His Research Center for Group Dynamics soon became the central training center for mainstream social psychologists. By the end of World War II "M.I.T was the center of the new look in American social psychology, and when the Center [after Lewin's death in 1947] moved to the University of Michigan . . . , so did the center of gravity of the field." 24

The establishment of the Center at Michigan provided a distinct Lewinian background for the researchers who around that time became interested in the motivation of voting choices.

The involvement of the Survey Research Center (SRC) of the University of Michigan in election studies occurred almost by accident. In 1948 the SRC conducted a survey on public policy issues, which included one question on voting intentions for the presidential election that year. After Truman's surprise victory, which equally upset his opponent Dewey and the established commercial pollsters, it turned out that only the SRC had correctly gauged the mood of the nation. The Social Science Research Council established a Committee on Political Behavior to investigate the causes of the pollsters' inaccurate predictions, and more general, to discuss the future of election studies. The SRC, in turn, went back to their sample for a short post-election interview, eventually resulting in the first Michigan contribution to electoral research (The People Elect a President, 1952). Early in 1952 the Carnegie Corporation issued a grant to the Committee to fund a study of the 1952 U.S. Presidential elections, and the Committee commissioned the SRC to carry out the research, reported two years later in The Voter Decides.

The SRC brought to the study of voting a distinct outlook and experience in research. The Center evolved out of the Division of Program Surveys of the U.S. Department of Agriculture, a governmental research unit that during the World War had investigated consumer behavior. After the War the Division moved to Michigan and became the SRC, first under the directorship of Rensis Likert, later under Angus Campbell.

Three important aspects stood out in the work of the SRC and its predecessor. First, there was an emphasis on the measurement of attitudes and their origins in perceptions, past experience and general motives, growing out of Likert's early work on attitude scaling and measurement. Second, the Center employed national probability samples in its research designs, instead of the quota samples that the polling agencies had used in the 1948 elections forecasts. Finally, the SRC encouraged the use of open interview questions. ${ }^{25}$

Besides the research experience of the SRC, other factors influenced the formative years of the first Michigan studies as well. In preparation of the 1952 election study 
SRC Director Campbell assembled a weekly seminar of scholars, in which plans for the study were laid out and discussed. In this seminar there was a strong influence from social psychologists M. Brewster Smith, Daniel Katz, Theodore Newcomb, Gerald Gurin and Campbell himself, besides political scientists Warren Miller and George Belknap. Additional important influences came from psychologists in the Research Center for Group Dynamics, who carried the Lewinian emphasis on field psychology into the Michigan works. ${ }^{26}$

The SRC was also influenced, but in a more negative sense, by the earlier election research, including Lazarsfeld's Erie County study. The Michigan group considered these older studies for the greater part as a mere opinion demography, a relating of opinions and attitudes to face sheet data like age, sex, education and socioeconomic status. This method was given a sociological rationale in Lazarsfeld's work, in which group membership serves as the basis of political behavior. Such sociological approaches were held to have little explanatory power: first, because shifts between the major parties generally could be found in all social groups; second, because there was too little change in the relative size of these groups to account for these shifts. Furthermore, the approaches gave no important information on the factors that mediate between social characteristics and the vote. 27

From these positive and negative influences the SRC group developed a basic Lewinian view of voting action. The voting action results from a field of socio-political forces, a life space including the voter and the social-political world as it exists for him. Inner needs and past experience will charge certain regions of the political life space with positive valence and others with negative valence, setting up a field of forces directing voting action. Campbell et al. expressed this charging process in terms of attitudes, defined as "orientations to the elements of national politics, seen by the voter as negative or positive." 28 When the attitudinal forces in the field are so distributed that a strong resultant force in the direction of one candidate exists, the corresponding voting action will occur without delay. When, however, the forces point in strongly divergent directions, the voter will vacillate between possible candidates and the consummatory voting action will be postponed or even cancelled. ${ }^{29}$

An influential part of the Michigan research was reserved for the analysis of the cognitive structure of the socio-political field, i.e., the number of different elements that exist for the voter and the degree to which he sees these elements as connected to one another. It was found that these fields in general displayed relatively low levels of organization ("levels of conceptualization" in the Michigan terminology); whatever organization existed in the field could be largely contributed to the pervasive influence of party identification, the voter's feeling of attachment to one of the parties. ${ }^{30}$

The publication of The American Voter is generally viewed as a landmark point in the study of voting action. The analyses provided by Angus Campbell, Converse, Miller and Stokes are skillfull and provoking, and no single study before or after it has matched the scope and variety of the materials presented in The American Voter. Yet, in spite of their claims to the contrary, the work of the Michigan researchers showed a fundamental continuity with the research by Lazarsfeld et al., as we will point out in the final section.

\section{The Two Schools Revisited: Discussion and Conclusions}

In the previous pages we have discussed two distinct theories of voting action with their psychological antecedents. It is often noted that the Columbia approach represents 
a mainly "sociological" view of voting behavior, while the Michigan model is more "psychological" in nature. In this final section we will contend that there is much similarity between the schools, both with regard to their psychological origins as to their principal conclusions.

Regarded by their psychological origins, both schools essentially employ action theories as the framework of analysis. Central to Lazarsfeld's analysis of action was an inquiry into the process in which a certain behavioral intention develops into a consummatory action; in the case of voting actions, perceptions of and attitudes towards the elements of politics and influences from the voter's social environment work to press the vote intention into a voting action. At any time the action is seen as codetermined by the state of the person and the state of the environment as he perceives it.

A theory of action was also explicit in the (early) work of Lewin, who sought to combine Freud's motivation theory and principles of Gestalt psychology in one dynamic model. He conceived of person and environment as one field of forces, directly determining action. Lewin's field theory laid the groundwork for the Michigan approach to voting research, in whose view voting action directly conforms to the resultant force of a field of forces, comprising the individual and the sociopolitical environment as he sees it. Both schools thus combined motivational and cognitive aspects in their models, and both schools admitted to explanations of voting action from the point of view of the voter.

The similarity in psychological origins is reflected in some of the major conclusions of the Columbia and Michigan schools. Most importantly, there is a basic equivalence between Michigan's finding that a conflict of forces in the field will reduce or divert the voting response and the Columbia conclusion that the occurrence of social and attitudinal cross-pressures impedes implementation of a voting intention into a consummatory voting action. ${ }^{31}$ Further, the schools agree on the pervasive impact of the voter's partisan loyalty (or party identification) with respect to the resolution of conflicting attitudinal forces. ${ }^{32}$ Finally, there is also consensus on the important role of primary and secondary groups in the establishment and maintenance of the voter's partisan allegiance. ${ }^{33}$

Lazarsfeld has repeatedly pointed out basic similarities between his own and Lewin's approach. Like Lazarsfeld's attempts, Lewin's early action research in Berlin covered all aspects of the action sequence, holding out a promise of an integrated theory of goals, intentions and occasions, which promise, however, had not been fulfilled.$^{34}$ Lazarsfeld's emphasis on implementation, "the way in which more or less vague dispositions, intentions and interests . . . may lead . . . to the performance of a specific act like buying a car, going on a trip, or voting for a candidate" is equivalent to Lewin's notion of locomotion through psychological space. ${ }^{35}$ In a wider context, Lazarsfeld has called attention to the fact that the Columbia school's findings on group conformity pressures, attitudinal cross-pressures and selective perception are comparable to the findings of Gestalt theorists concerning tendencies toward balancing in interpersonal relations and dissonance reduction in individuals. ${ }^{36}$

The Michigan scholars, however, have consistently denied any similarity between Lazarsfeld's and their own approach. From the very beginning to the very last ${ }^{37}$ they have converted Lazarsfeld's theory into a sociological straw man, which could be knocked down with a simple reference to the immobility of social characteristics in the face of important political changes. We have indicated that The People's Choice indeed suffered from a certain amount of sociological onesidedness, yet the remaining discussion of Lazarsfeld's work and ideas should also have made it clear that Michigan's perception of the Columbia research suffers form serious distortion. 


\section{ACKNOWLEDGMENTS}

I wish to thank Jacques Thomassen, Kees Aarts, Erwin Seydel (University of Twente), Warren Miller (Arizona State University) and the editor and anonymous referees of the Journal of the History of the Behavioral Sciences for their valuable comments on earlier drafts of this paper. I am also indebted to Pete Rowland and Lawrence Wrightsman for their guidance in the field of psychology during my stay at the University of Kansas, 1989-1990. Financial support for this research from the Netherlands Organization for the Advancement of Research (NWO) is gratefully acknowledged (grant nr. 430-214-032).

\section{NoTES}

1. The Bureau of Applied Social Research that Lazarsfeld founded at Columbia and headed for three decades was in many aspects the successor of the "Forschungsstelle." See Paul F. Lazarsfeld, "Forty Years Later: Foreword to the English Edition," in Marie Jahoda, Paul F. Lazarsfeld and Hans Zeisel, Marienthal. The Sociography of an Unemployed Community (Chicago: Aldine, 1971), p. xv; David L. Sills, "Lazarsfeld, Paul F.", in International Encyclopedia of the Social Sciences Vol. 18, David L. Sills, Ed. (NY: MacMillan \& Free Press, 1979), p. 412; Hans Zeisel, "L'école viennoise des recherches de motivation," Revue française de sociologie 9 (1968): 3-12.

2. Sills, "Lazarsfeld," p. 417.

3. Paul F. Lazarsfeld et al., Jugend und Beruf. Kritik und Material (Jena: Fischer, 1931), p. 28.

4. Paul F. Lazarsfeld, "The Psychological Aspect of Market Research," Harvard Business Review 13 (1934): 54-71; Arthur Kornhauser and Paul F. Lazarsfeld, "The Analysis of Consumer Actions," in The Language of Social Research, Paul F. Lazarsfeld and Morris Rosenberg, Eds. (Glencoe, Ill.: Free Press, 1955), pp. 392-419.

5. Kornhauer \& Lazarsfeld, "The Analysis of Consumer Actions," pp. 394, 395.

6. Lazarsfeld, "Psychological Aspect," p. 61; see also Paul F. Lazarsfeld, "Reflections on Business," American Journal of Sociology 65 (1959): 2-5; for a general methodological introduction Hans Zeisel, Say It with Figures, 6th ed. (NY: Harper \& Row, 1985), pp. 186-203. Lazarsfeld has extensively reviewed his own action research in "Historical Notes on the Empirical Study of Action: An Intellectual Odyssey," in his Qualitative and Quantitative Analysis. Historical and Critical Essays (Boston: Allyn \& Bacon, 1972), pp. 53-105, and in "Working with Merton," in The Idea of Social Structure. Papers in Honor of Robert K. Merton, Lewis A. Coser, Ed. (NY: Harcourt Brace Jovanovich, 1975), pp. 45-56.

7. The circumstances surrounding the 1940 study are fully documented in Peter H. Rossi, "Four Landmarks in Voting Research," in American Voting Behavior, Eugene Burdick and Arthur J. Brodtbeck, Eds. (Glencoe, Ill.: Free Press, 1959), pp. 15-20.

8. Paul F. Lazarsfeld, Bernard R. Berelson and Hazel Gaudet, The People's Choice, How the Voter Makes up his Mind in a Presidential Campaign. 2nd ed. (NY: Columbia University Press, 1948), pp. 16ff.

9. Ibid., pp. $137 \mathrm{ff}$.

10. Ibid., pp. $73 \mathrm{ff}, 150 \mathrm{ff}$.

11. Ibid., pp. $56 \mathrm{ff}$.

12. Ibid., p. 27. Part of this onesideness was undoubtedly due to the still nascent state of academic sociology and psychology at that time; having been deprived of his own model of action, there was little work for Lazarsfeld to fall back upon (Rossi, "Four Landmarks," p. 23).

13. Rossi, "Four Landmarks," pp. 24-26.

14. Bernard R. Berelson, Paul F. Lazarsfeld and William N. McPhee, Voting. A Study of Opinion Formation in a Presidential Campaign (Chicago: University of Chicago Press, 1954), pp. $77 \mathrm{ff}$.

15. Ibid., pp. $118 \mathrm{ff}, 182 \mathrm{ff}$.

16. Ibid., pp. 215-233.

17. Most important in this respect was a collaborative effort of four Columbia researchers toward a comparative study of the social psychology of voting, which resulted in a long review article (Seymour M. Lipset, Paul F. Lazarsfeld, Allen H. Barton and Juan J. Linz, "The Psychology of Voting. An Analysis of Political Behavior," in Handbook of Social Psychology, Vol. II, Gardner Lindzey, Ed. (Reading, MA: Addison-Wesley, 1954), pp. 1124-1175) and in three chapters in Seymour M. Lipset, Political Man. The Social Bases of Politics, exp. ed. (Baltimore: John Hopkins University Press, 1981), pp. 183-300.

18. Sills, "Lazarsfeld," p. 415. 
19. Jean M. Mandler and George Mandler, "The Diaspora of Experimental Psychology: the Gestaltists and Others," in The Intellectual Migration. Europe and America, 1930-1960, Donald Fleming and Bernard Bailyn, Eds. (Cambridge, MA: Harvard University Press, 1969), pp. 399-405.

20. Edwin G. Boring, A History of Experimental Psychology, 2nd ed. (NY: Appleton-Century-Crofts, 1950), pp. 714, 723; Heinz Heckhausen, Motivation and Action (Berlin: Springer, 1991), pp. 29, 118, 124, 127; David Rapaport, Ed., Organization and Pathology of Thought. Selected Sources (NY: Columbia University Press, 1951), pp. 95 n.1, 117 n.54.

21. For an early principal statement of the field theory of action see Kurt Lewin, Vorsatz, Wille und Bedürfnis. Mit Vorbemerkungen über die psychischen Kräfte und Energien und über die Struktur der Seele (Berlin: Springer, 1926). An abridged English version of this paper appeared in Willis D. Ellis, Ed., A Source Book of Gestalt Psychology (London: Routledge \& Kegan Paul, 1938), pp. 283-299, and a full translation in three separate pieces in Kurt Lewin, A Dynamic Theory of Personality. Selected Papers (NY: McGraw-Hill, 1935), pp. 43-65, and in Rapaport, Organization and Pathology, pp. 76-94, 95-153. See for later applications Kurt Lewin, Field Theory in Social Science. Selected Theoretical Papers (NY: Harper \& Row, 1951).

22. Thomas H. Leahy, A History of Modern Psychology (Englewood Cliffs, NJ: Prentice Hall, 1991), p. 76. 23. See Lewin's own applications in his Resolving Social Conflicts. Selected Papers on Group Dynamics (NY: Harper \& Row, 1948), and his "Group Decision and Social Change," in Readings in Social Psychology, 3rd ed., Eleanor E. Maccoby, Theodore M. Newcomb and Eugene L. Hartley, Eds. (NY: Holt, Rinehart \& Winston, 1958), pp. 174-183. For a review see Morton Deutsch, "Field Theory," in International Encyclopedia, Vol. 5, Sills, Ed., pp. 406-417.

24. Mandler \& Mandler, "The Diaspora," p. 405.

25. For more extensive reviews on the background of the SRC, see Rensis Likert, "The Sample Interview Survey as a Tool of Research and Policy Formation," in The Policy Sciences, Daniel Lerner and Harold D. Lasswell, Eds. (Stanford, CA: Stanford University Press, 1951), pp. 234-239; Warren E. Miller, "An Organizational History of the Intellectual Origins of the American National Election Studies" (paper presented at the Conference on the History of Election Studies, University of Tente, 1990); Rossi, "Four Landmarks," pp. 36-38; M. Brewster Smith, "Opinions, Personality, and Political Behavior," American Political Science Review 52 (1958): 6-9.

26. Angus Campbell, Philip E. Converse, Warren E. Miller and Donald E. Stokes, The American Voter (NY: Wiley, 1960), pp. 33ff; Miller, "An Organizational History," p. 9.

27. Angus Campbell, Gerald Gurin and Warren E. Miller, The Voter Decides (Evanston, IL: Row \& Peterson, 1954), pp. 84-86; Campbell et al., The American Voter, pp. 17, 36-37, 43, 64-66; Morris Janowitz and Warren E. Miller, "The Index of Political Predisposition in the 1948 Elections," Journal of Politics 14 (1952): 710-727.

28. Campbell et al., The American Voter, p. 66.

29. Campbell et al., The Voter Decides, pp. 87, 157ff, 181-184; Campbell et al., The American Voter, pp. 76ff. 30. Campbell et al., The American Voter, pp. 168ff; Philip E. Converse, "The Nature of Belief Systems in Mass Publics," in Ideology and Discontent, David E. Apter, Ed. (NY: Free Press, 1964), pp. $206-261$. 31. Compare Berelson et al., Voting, pp. 118ff, 182ff; Lazarsfeld et al., The People's Choice, pp. xxxiii-xxxiv, 56ff; Lipset et al., "The Psychology of Voting," pp. 1154-1155, to Campbell et al., The Voter Decides, pp. 87, 157ff, 181-184; Campbell et al., The American Voter, pp. 76ff.

32. Compare Lazarsfeld et al., The People's Choice, pp. xxxvi-xxxvii; Lipset et al., "The Psychology of Voting," pp. 1160-1164, to Campbell et al., The American Voter, pp. $120 \mathrm{ff}$.

33. Compare Berelson et al., Voting, pp. 54ff; Lazarsfeld et al., The People's Choice, pp. 16ff, 137ff; Lipset et al., "The Psychology of Voting," pp. 1144-1150, to Campbell et al., The Voter Decides, pp. 199ff; Campbell et al., The American Voter, pp. 61-63, 76-77, 146ff, 295ff.

34. Lazarsfeld, “Historical Notes," pp. 67-76.

35. Berelson et al., Voting, pp. 278-279; Lazarsfeld et al., The People's Choice, p. 163 n. 2.

36. Berelson et al., Voting, pp. 284-285.

37. Compare for example Janowitz and Miller, "The Index," pp. 711-713, and J. Merril Shanks and Warren E. Miller, "Policy Direction and Performance Evaluation: Complementary Explanations of the Reagan Elections," British Journal of Political Science 20 (1990): 149-150. 